\title{
SEED DEPOSITION BY BIRDS ON ARTIFICIAL PERCHES AT DIFFERENT DISTANCES FROM A GALLERY FOREST IN THE CERRADO AREA
}

\author{
Ademir Kleber Morbeck de Oliveira ${ }^{1 *}$, Ricardo Anghinoni Bocchese ${ }^{1}$, Kátia Raulickis Fortes Pereira $^{2}$, Thiago \\ Dutra de Carvalho ${ }^{2}$
${ }^{1}$ University of Anhanguera, Graduate Program in Environment and Regional Development, Campo Grande, Mato Grosso do Sul, Brazil - akmorbeckoliveira@gmail.com*;
${ }^{2}$ University of Anhanguera, Biological Sciences, Campo Grande, Mato Grosso do Sul, Brazil, bocchese.ra@gmail.com, krfortesp@gmail.com, biotdc@gmail.com

Received for publication: 13/09/2017 - Accepted for publication: 02/04/2018

\begin{abstract}
The objective of this study was to evaluate the deposition of seeds under artificial perches located at different distances from a gallery forest in the Cerrado area in the city of Campo Grande, state of Mato Grosso do Sul, Brazil. The experiment was carried out at the Fazenda Escola Três Barras where 20 crude eucalyptus artificial perches were deployed at distances of 10, 20, 40 and 80 meters from the edge of a 400 meter long forest. Data collection was performed every two weeks for a period of one year. A bird survey was carried out at the same time and a total of 190 hours of direct observation were made. Overall, 21,283 seeds were collected beneath the perches; these came from 27 plant species, with the most abundant representation from the pioneer tree species Cecropia pachystachya, Miconia elegans and Myrsine coriacea (93.31\% of total seeds). The survey of birds identified 77 species, with a predominance of insectivorous and omnivorous types. The results indicated that perches installed at the greatest distance from the forest area yielded a lower seed deposition rate, demonstrating that distance determines the effectiveness of the artificial perches, although they are still able to attract some bird species. The results of the experiment demonstrated that use of artificial perches is an effective method to promote the deposition of seeds in areas without tree vegetation, favoring the creation of a seed bank. Keywords: Frugivory, nucleation, seed rain, seed dispersal.
\end{abstract}

\section{Resumo}

Deposição de sementes por aves sob poleiros artificiais a diferentes distâncias de mata de galeria em área de Cerrado. Objetivou-se com esta pesquisa avaliar a deposição de sementes sob poleiros artificiais posicionados a diferentes distâncias de um trecho de mata de galeria, em área de Cerrado no município de Campo Grande, Mato Grosso do Sul, Brasil. O experimento foi conduzido na Fazenda Escola Três Barras, onde foram implantados 20 poleiros artificiais de eucalipto bruto em distâncias de 10, 20, 40 e 80 metros da borda de um trecho de 400 metros da mata. A coleta de dados foi realizada quinzenalmente durante o período de um ano, abrangendo um ciclo sazonal. Paralelamente foi realizado um levantamento da avifauna que totalizou 190 horas de observação direta. Nos poleiros foram recolhidas 21.283 sementes, pertencentes a 27 espécies vegetais, sendo as mais representativas as arbóreas pioneiras Cecropia pachystachya, Miconia elegans e Myrsine coriacea, com $93,31 \%$ do total. Em relação as aves foram registradas 77 espécies com o predomínio de insetívoras e onívoras. Os resultados indicaram que apenas os poleiros instalados a maiores intervalos da área de mata apresentaram uma menor deposição de sementes, demonstrando que a partir de determinadas distâncias, os poleiros artificiais são menos eficazes, embora ainda sejam capazes de atrair algumas espécies de aves. Os resultados do experimento demonstraram que a utilização de poleiros artificiais é uma metodologia eficaz para promover a deposição de sementes em áreas sem vegetação arbórea, propiciando a criação de um banco de sementes.

Palavras-chave: Frugivoria, nucleação, chuva de sementes, dispersão de sementes.

\section{INTRODUCTION}

In tropical regions, about 50 to $90 \%$ of tree species depend on zoochory for dispersal of their seeds; this dispersal is carried out mainly by avifauna (ATHIÊ; DIAS, 2016) and is termed ornithochory. Specialized frugivorous usually occur at low densities and tend to be rare in areas of degraded forest (CAVES et al., 2013); in these areas, fruits and seeds are mainly consumed by insectivorous and omnivorous groups of birds (BOCCHESE et al., 2008). 
Generally, the movement of birds that disperse forest seeds to open or degraded areas is limited due to exposure to predation and also to the absence or restricted number of landing and foraging sites (GRAHAM; PAGE, 2012). Given that the low rate of seed supply is a limiting factor in the regeneration and recovery of degraded areas, then manipulation of the direction of the "seed rain"- the set of seeds and fruits produced by forest vegetation that is dispersed by animals (zoochory) or wind (anemochory) - to specific areas could replenish the soil seed bank and increase the establishment of seedlings (CARLO; YANG, 2011).

Several techniques can be used for forest restoration; one of the most important is the provision of artificial perches for birds. Defined as a nucleator technique, perches placed in open areas tend to establish nuclei of diversity that radiate naturally and respect the natural succession processes (REIS et al., 2010). Studies on long-distance dispersal indicate that the ideal scale of seed transport depends on local factors, such as type, spatial structure, level of conservation of the ecosystems, and the distance of the sources of propagules (NATHAN et al., 2003).

Therefore, determining the dispersion distances of seeds of forest species is a vital tool for the recovery process, especially in degraded areas in which natural regeneration must be reestablished through the succession of species (ZIMMERMANN et al., 2015).

Taking into account the importance of ornithochoric dispersion for the recovery of altered and/or degraded areas, the present study was initiated to test the hypothesis that installation of artificial perches mounted at different distances from the edge of a forest formation could influence the rate of seed deposition by birds.

\section{MATERIAL AND METHODS}

\section{Characterization of the study area}

The study was carried out in a section parallel to the Permanent Preservation Area of the Três Barras stream, at the Fazenda Escola Três Barras (20³3' 58.71" S; 54 32' 22.47" W), in the municipality of Campo Grande, state of Mato Grosso do Sul, Brazil. According to the classification of Köppen-Geiger, the climate of Campo Grande is between subtypes Cfa, mesothermal moist without dry season or with a short period of drought, and Aw, humid tropical with a hot and rainy season in the summer and dry season in the winter. The annual average rainfall is $1,430.1 \mathrm{~mm}$ and the average annual temperature is $22.7^{\circ} \mathrm{C}$.

The region is used for soybean and corn cultivation and also contains eucalyptus plantations. Fragments of cerradões, seasonal forests and gallery forests, are present and are characterized by the selective removal of wood for use in urban and rural constructions. For this reason, the current process of ecological succession is dominated by pioneer and secondary species (secondary formations). The common species in these forests are Alibertia edulis (Rich.) A. Rich., Anadenanthera colubrina (Vell.) Brenan, Aspidosperma macrocarpon Mart., Cordia glabrata (Mart.) A. DC., Hancornia speciosa Gomes, Jacaranda decurrens Cham., Miconia albicans (Sw.) Triana, Stryphnodendron adstringens (Mart.) Coville, and Vochysia tucanorum Mart. The classification of plant species in the study area was performed by the Phylogeny Group of Angiosperms (PGA).

\section{Location of artificial perches and seed collectors}

In November 2010, twenty artificial perches were installed along a stretch of 400 meters from the edge of the gallery forest on the left bank of the Três Barras stream, in a pasture area covered with Urochloa brizantha (Hochst. ex A. Rich.) R.D. Webster. The perches were made of raw (untreated) eucalyptus with a diameter of $20 \mathrm{~cm}$ and constructed in a cross shape with a height of 3.5 meters. A cylindrical eucalyptus rod 1 meter long and 5 centimeters in diameter was fixed horizontally to the top of each vertical pole; this horizontal rod served as landing area for birds.

The 20 perches were positioned in the pasture at distances of 10, 20, 40 and 80 meters from the edge of the forest, with five replicates; these distances were considered as the "treatment" in the experiment. The experiment was performed using a complete randomized block (CRB) design. The data were analyzed using the non-parametric Mann-Whitney test (U-test). A correlation test (Pearson's coefficient) was carried out to examine the relationship between the abundance of seeds collected per treatment per month and the accumulated monthly rainfall during the whole experiment.

Seeds present in the feces of birds were collected using two rectangular wooden collectors $(60 \mathrm{x} 30 \mathrm{x}$ $10 \mathrm{~cm}$ ) under each perch. A nylon screen with a $1.0 \mathrm{~mm}$ mesh was attached to the base of each collector. Both collectors were suspended by thin wire about $30 \mathrm{~cm}$ from the transverse stem of the perch. A total of 40 collectors were used in the experiment.

Data collection was performed every two weeks from December 2010 (the month in which the perches were installed) to January 2012. The collected seeds were sorted, counted, and identified using a stereomicroscope, specialized literature, and consultation of plant seed specialists. 


\section{Bird survey}

During the study period, a survey of the avifauna species present in the area was performed in order to identify potential seed dispersers. The survey was carried out fortnightly on random transects inside the gallery forest and in the open area, and from fixed points of observation in the perch area. Overall, 190 hours of observation were made during the experiment. The avifauna were classified into three trophic categories: frugivores, insectivores, and omnivores (SICK, 1997); scientific nomenclature of the species was based on the Brazilian Committee of Ornithological Records.

\section{RESULTS}

During the experimental period, 21,283 seeds belonging to 27 plant species were collected. Out of the total, $96.02 \%$ belonged to 10 species from nine botanical families (Table 1). The remaining seeds $(3.97 \%)$ belonged to 17 morphospecies that could not be identified.

Table 1. Species, family, growth form, number and proportion of seeds collected under artificial perches, at the Fazenda Escola Três Barras, municipality of Campo Grande, state of Mato Grosso do Sul, Brazil

Tabela 1. Famílias, espécies, forma de vida, número e percentagens de sementes coletadas sob poleiros artificiais, na Fazenda Escola Três Barras, município de Campo Grande, Mato Grosso do Sul.

\begin{tabular}{cccc}
\hline Families & Growth form & Seeds & $\%$ \\
\hline Dilleniaceae & Doliocarpus dentatus (Aubl.) Standl. - climbing & 151 & 0.71 \\
Erytroxylaceae & Erythroxylum deciduum A.St.-Hil. - tree & 56 & 0.26 \\
Melastomataceae & Miconia cinnamomifolia (DC.) Naudin - tree & 47 & 0.22 \\
& Miconia elegans Cogn. - tree & 7.186 & 33.76 \\
Myrsinaceae & Myrsine coriacea (Sw.) R.Br. ex Roem. \& Schult. - tree & 2.563 & 12.04 \\
Myrtaceae & Eugenia florida DC. - shrub & 16 & 0.07 \\
Nyctaginaceae & Guapira graciliflora (Mart. ex Schmidt) Lundell - tree & 28 & 0.13 \\
Rubiaceae & Psychotria carthagenensis Jacq. - tree & 80 & 0.38 \\
Ulmaceae & Trema micrantha (L.) Blume - tree & 200 & 0.94 \\
Urticaceae & Cecropia pachystachya Trécul - tree & 10.110 & 47.50 \\
Not identified & Morphospecies 1 & 272 & 1.28 \\
Not identified & Morphospecies 2 & 209 & 0.98 \\
Not identified & Morphospecies 3 & 149 & 0.70 \\
Not identified & Morphospecies 4 & 80 & 0.38 \\
Not identified & Morphospecies 5 & 44 & 0.21 \\
Not identified & Others (12 morphospecies) & 92 & 0.43 \\
\hline Total & & 21,283 & 100 \\
\hline
\end{tabular}

Two of the species identified (Miconia elegans and Miconia cinnamomifolia) belonged to the family Melastomataceae. The other identified species each belonged to a different plant family. Seeds of Cecropia pachystachya, Miconia elegans, and Myrsine coriacea were the most abundant in the collectors $(93.31 \%$ of the total, $\mathrm{n}=19,859$ ) (Figure 1). Seeds of Cecropia pachystachya and Myrsine coriacea were present in all collections. Seeds of Cecropia pachystachya were most abundant in March and April, and those of Myrsine coriacea showed peak abundance in December. Miconia elegans seeds were only found in June, July, August, and November. 


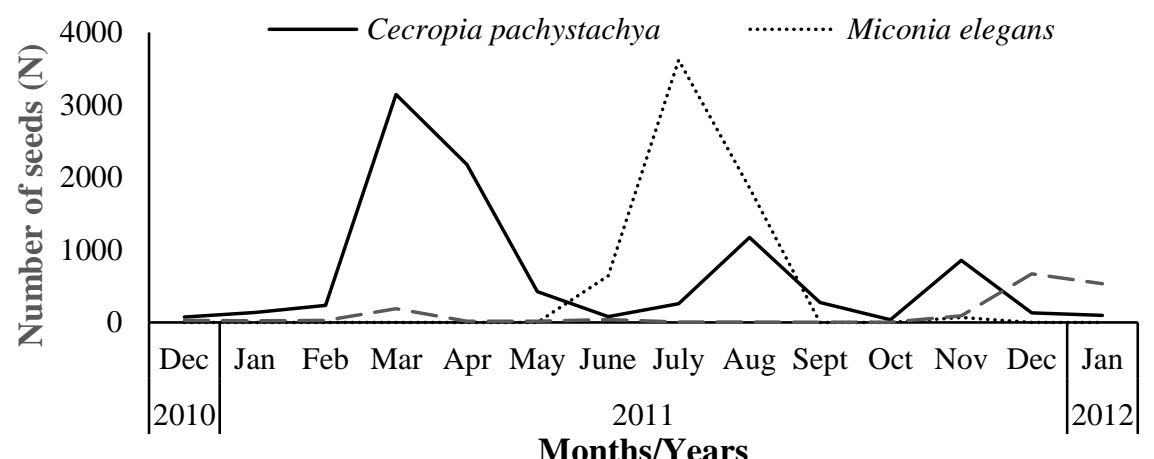

Figure 1. Seed abundance of the three representative species, collected at the Fazenda Escola Três Barras, municipality of Campo Grande, state of Mato Grosso do Sul, Brazil.

Figura 1. Abundância de sementes das três espécies mais representativas, coletadas na Fazenda Escola Três Barras, município de Campo Grande, Mato Grosso do Sul.

Analysis of the relationship of the "seed rain" to distance from the forest using a U-test showed a significant difference only for the 80 meter perches (Table 2), indicating that seed input was only affected at the greatest distance used in the study. An evaluation of the relationship between seed transport rate and accumulated monthly rainfall indicated that there was no direct relationship between these factors $(r=0.239, p=0.075$; Figure 2).

Table 2. Total number and average of seeds under artificial perches at different distances from the forest, at the Fazenda Escola Três Barras, municipality of Campo Grande, state of Mato Grosso do Sul, Brazil.

Tabela 2. Número total e média de sementes coletadas sob os poleiros a diferentes distâncias da mata de galeria, na Fazenda Escola Três Barras, Campo Grande, Mato Grosso do Sul.

\begin{tabular}{ccc}
\hline Treatment (distance) & Number of seeds collected & Mean \\
\hline 10 meters & 5666 & $1133.2 \mathrm{a}$ \\
20 meters & 6003 & $1200.6 \mathrm{a}$ \\
40 meters & 7617 & $1503.4 \mathrm{a}$ \\
80 meters & 2107 & $421.4 \mathrm{~b}$
\end{tabular}

Significant differences by the non-parametric Mann-Whitney test (U-test) are indicated by different letters.

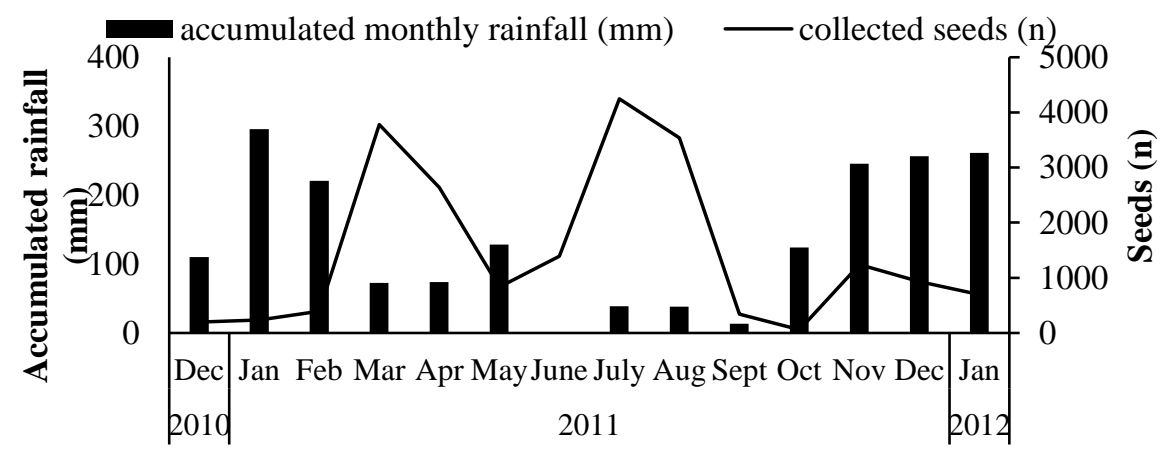

Months/Years

Figure 2. Mensal accumulated rainfall and seed abundance collected under artificial perches, at the Fazenda Escola Três Barras, municipality of Campo Grande, state of Mato Grosso do Sul, Brazil.

Figura 2. Precipitação acumulada mensal e abundância de sementes coletadas sob poleiros artificiais, na Fazenda Escola Três Barras, município de Campo Grande, Mato Grosso do Sul.

The screening of the avifauna on the perches identified 77 species belonging to 15 orders; 43 species belonged to the order 'Passeriformes' (Table 3), with the family Tyrannidae being most abundantly represented (17 species), most of which have an insectivorous habit. Insectivorous species predominated in the survey, with a total of 41 species (53.24\%); omnivorous species were next most common (25 species, $32.47 \%$ ), and typically frugivorous species were least frequent $(11,14.29 \%)$ (Table 3). 
Table 3. List of bird species recorded during the study period, at the Fazenda Escola Três Barras, municipality of Campo Grande, state of Mato Grosso do Sul, Brazil.

Tabela 3. Lista de espécies de aves registradas durante o período de estudo, na Fazenda Escola Três-Barras, município de Campo Grande, Mato Grosso do Sul.

\begin{tabular}{l}
\hline Species/Family/Order \\
\hline RHEIFORMES Forbes, 1884 \\
Rheidae Bonaparte, 1849 \\
Rhea americana (Linnaeus, 1758) \\
TINAMIFORMES Huxley, 1872 \\
Tinamidae Gray, 1840 \\
Crypturellus undulatus (Temminck, 1815) \\
Crypturellus parvirostris (Wagler, 1827) \\
Crypturellus tataupa (Temminck, 1815) \\
Rhynchotus rufescens (Temminck, 1815) \\
Nothura maculosa (Temminck, 1815)
\end{tabular}

ANSERIFORMES Linnaeus, 1758

Anatidae Leach, 1820

Dendrocygna autumnalis (Linnaeus, 1758)

Amazonetta brasiliensis (Gmelin, 1789)

PELECANIFORMES Sharpe, 1891

Bubulcus ibis (Linnaeus, 1758)

Threskiornithidae Poche, 1904

Mesembrinibis cayennensis (Gmelin, 1789)

Theristicus caudatus (Boddaert, 1783)

FALCONIFORMES Bonaparte, 1831

Falconidae Leach, 1820

Caracara plancus (Miller, 1777)

Milvago chimachima (Vieillot, 1816)

CARIANIFORMES Furbringer, 1888

Cariamidae Bonaparte, 1850

Cariama cristata (Linnaeus, 1766)

Vanellus chilensis (Molina, 1782)

GRUIFORMES Bonaparte, 1854

Rallidae Rafinesque, 1815

Porzana albicollis (Vieillot, 1819)

PSITTACIFORMES Wagler, 1830

Psittacidae Rafinesque, 1815

Amazona aestiva (Linnaeus, 1758)

Aratinga aurea (Gmelin, 1788)

Brotogeris chiriri (Vieillot, 1818)

Ara ararauna (Linnaeus, 1758)

CUCULIFORMES Wagler, 1830

Cuculidae Leach, 1820

Crotophaga ani Linnaeus, 1758

Guira guira (Gmelin, 1788)

Piaya cayana (Linnaeus, 1766)

STRIGIFORMES Wagler, 1830

Strigidae Leach, 1820

Category trophic Potential disperser

omnivore

omnivore

omnivore

omnivore

omnivore

frugivore

omnivore

omnivore

insectivore

omnivore

omnivore

omnivore

X

omnivore

X

omnivore

X

omnivore

X

omnivore

frugivore

X

frugivore $\mathrm{X}$

frugivore $\mathrm{X}$

frugivore $\mathrm{X}$

insectivore

insectivore

insectivore

omnivore

X

FLORESTA, Curitiba, PR, v. 48, n. 3, p. 363-372, jul/set. 2018.

Oliveira A.K.M. et.al.

ISSN eletrônico 1982-4688 
Athene cunicularia (Molina, 1782)

Glaucidium brasilianum (Gmelin, 1788)

insectivore

TROGONIFORMES A. O. U., 1886

Trogonidae Lesson, 1828

Trogon surrucura Vieillot, 1817

omnivore

CORACIIFORMES Forbes, 1844

Momotidae Gray, 1840

Momotus momota (Linnaeus, 1766)

insectivore

GALBULIFORMES Fürbringer, 1888

Galbulidae Vigors, 1825

Galbula ruficauda Cuvier, 1816

insectivore

PICIFORMES Meyer \& Wolf, 1810

Ramphastidae Vigors, 1825

Pteroglossus castanotis Gould, 1834

Ramphastos toco Statius Muller, 1776

Picidae Leach, 1820

Colaptes campestris (Vieillot, 1818)

Dryocopus lineatus Linnaeus, 1766

Picumnus albosquamatus d'Orbigny, 1840

Veniliornis passerinus (Linnaeus, 1766)

PASSERIFORMES Linnaeus, 1758

Thamnophilidae Swainson, 1824

Thamnophilus doliatus (Linnaeus, 1764)

Taraba major (Vieillot, 1816)

Dendrocolaptidae Gray, 1840

Furnarius rufus (Gmelin, 1788)

Rhynchocyclinae Berlepsch, 1907

Todirostrum cinereum (Linnaeus, 1766)

Tyrannidae Vigors, 1825

Camptostoma obsoletum (Temminck, 1824)

Elaenia flavogaster (Thunberg, 1822)

Elaenia spectabilis Pelzeln, 1868

Gubernetes yetapa (Vieillot, 1818)

Machetornis rixosa (Vieillot, 1819)

Megarynchus pitangua (Linnaeus, 1766)

Myiarchus ferox (Gmelin, 1789)

Myiarchus tyrannulus (Statius Muller, 1776)

Myiozetetes cayanensis (Linnaeus, 1766)

Myiozetetes similis (Spix, 1825)

Pitangus sulphuratus (Linnaeus, 1766)

Pyrocephalus rubinus (Boddaert, 1783)

Suiriri suiriri (Vieillot, 1818)

Tyrannus melancholicus Vieillot, 1819

frugivore

X

omnivore

$\mathrm{X}$

insectivore

insectivore

insectivore

insectivore

insectivore

insectivore

insectivore

insectivore

insectivore

insectivore

insectivore

insectivore

insectivore

insectivore

insectivore

insectivore

insectivore

insectivore

insectivore

omnivore

insectivore

insectivore

insectivore

insectivore

Tyrannus savana Vieillot, 1808

insectivore

insectivore

Vireonidae Swainson, 1837

Cyclarhis gujanensis (Gmelin, 1789)

Corvidae Leach, 1820

omnivore

X 
Cyanocorax cristatellus (Temminck, 1823)

Hirundinidae Rafinesque, 1815

Progne tapera (Vieillot, 1817)

Hirundo rustica Linnaeus, 1758

Progne chalybea (Gmelin, 1789)

Stelgidopteryx ruficollis (Vieillot, 1817)

Troglodytidae Swainson, 1831

Troglodytes musculus Naumann, 1823

Turdidae Rafinesque, 1815

Turdus rufiventris Vieillot, 1818

Turdus leucomelas Vieillot, 1818

Mimidae Bonaparte, 1853

Mimus saturninus (Lichtenstein, 1823)

Motacillidae Horsfield, 1821

Anthus lutescens Pucheran, 1855

Thraupidae Cabanis, 1847

Tangara cayana (Linnaeus, 1766)

Tangara sayaca (Linnaeus, 1766)

Tersina viridis (Illiger, 1811)

Dacnis cayana (Linnaeus, 1766)

Parulidae Wetmore, Friedmann, Lincoln, Miller, Peters, van Rossem, Van Tyne \& Zimmer 1947

Basileuterus hypoleucus Bonaparte, 1830

Basileuterus flaveolus (Baird, 1865)

Icteridae Vigors, 1825

Icterus pyrrhopterus (Vieillot, 1819)

Gnorimopsar chopi (Vieillot, 1819)

Pseudoleistes guirahuro (Vieillot, 1819)

Sturnella superciliaris (Bonaparte, 1850)

Fringillidae Leach, 1820

Euphonia chlorotica (Linnaeus, 1766)

$\begin{array}{ll}\text { insectivore } & \\ \text { insectivore } & \\ \text { insectivore } & \\ \text { insectivore } & \\ \text { insectivore } & \mathrm{X} \\ \text { omnivore } & \mathrm{X} \\ \text { omnivore } & \mathrm{X} \\ \text { omnivore } & \\ \text { insectivore } & \\ \text { frugivore } & \mathrm{X} \\ \text { frugivore } \\ \text { frugivore } \\ \text { frugivore }\end{array}$

insectivore

insectivore

omnivore $\mathrm{X}$

omnivore $\mathrm{X}$

omnivore $\mathrm{X}$

insectivore

frugivore $\mathrm{X}$

Frugivorous and omnivorous birds of the orders Psittaciformes, Falconiformes, Carianiformes, Strigiformes, Trogoniformes, Piciformes, and Passeriformes, were considered as potential seed dispensers; 25 species $(32.4 \%)$ fell into these categories.

\section{DISCUSSION}

During the course of the experiment, seeds belonging to 27 plant species were identified in the collectors; the identities of 12 taxa were confirmed, including a vine, a shrub, and 10 tree species. In addition, we found seeds of Urochloa brizantha; this plant is a sub-spontaneous species present in pasture areas and the seeds may have been included in the samples due to their consumption by granivorous birds and/or by wind dispersion (anemochory). For these reasons, these seeds (10) were not included in the analysis.

Most of the seeds collected under the perches belonged to three species of pioneer tree, Cecropia pachystachya, Miconia elegans, and Myrsine coriacea (93.31\% of total seeds collected). These species usually develop in secondary forest successions or occupy the edges of forests or gallery forests in the Cerrado biome and all produce a large number of fruit annually that is consumed by avifauna; the seed abundances of these species collected on the perches in the different months of the study period reflected the timing of fruiting of these species.

The bird species identified here showed diverse food preferences, with omnivorous, granivorous, and insectivorous species occurring in the same environment. Some bird species show a semi-dependent behavior for forested environments, that is, they inhabit the interior or edges of forests, but occasionally move to open areas. Such species can consume tree fruits and be responsible for the dispersion of seeds to the sampling areas furthest

FLORESTA, Curitiba, PR, v. 48, n. 3, p. 363-372, jul/set. 2018. 
from the edge of the forest. After feeding on fruit in forested areas, these birds might move to open areas where they might rest on isolated trees, fence posts, and other types of perch. Generalist bird species might also contribute to the dispersion of seeds to open areas (ANJOS et al., 1997).

With regard to the dominance of pioneer species in the seed fall of zoochoric seeds, previous research carried out in tropical regions of South and Central America produced similar results to those obtained in this study. In an experiment in the Florencia region of Colômbia, Cotacio et al. (2009) found that the most abundant species responsible for zoochoric dispersion was Henriettella $\mathrm{cf}$. sylvestris Gleason (Melastomataceae), with 95.2\% of the recorded seeds. In the Terra-firme Forest of the Colombian Amazon, Castillo and Stevenson (2010) observed that the highest seed rates were obtained from species belonging to the families Urticaceae (genus Cecropia) and Melastomataceae.

Previous studies of seed rain and dispersal by birds in Brazil produced similar data to those reported here. In the Amazon forest, the seed rain recorded by Wieland et al. (2011) was mainly characterized by the presence of diaspores of two Cecropia species (C. concolor Wild and C. sciadophylla Mart.) and nine Miconia species (M. argyrophylla DC, $M$. burchellii Triana, $M$. dispar Benth., M. phanerostila Pilg, M. gratissima Benth. ex Triana, M. lepidota DC., M. pyrifolia Naudin, M. regelii Cogn., and M. tomentosa Benth.). In São Paulo State, Athiê and Dias (2016) reported that the seeds of Cecropia pachystachya and Miconia affinis DC. were the most abundant of those collected under artificial perches. In Minas Gerais, Braga et al. (2015) found that seeds of Cecropia hololeuca Miq. and Cecropia glaziovii Sneth were the most abundant in the seed rain. Silva and Pedroni (2014) reported that Miconia theizans (Bonpl.) Cogn. is one of the main species in the network between plants and seeddispersing birds.

The high occurrence of seeds from species in the family Melastomataceae identified in various studies could be explained by the fact that this is one of the main families in the tropical region, with the genus Miconia being one of the largest in this family. The fruit of species in this family is characteristically of the capsule or berry type and is a preferred food resource for many bird species. The large number of seeds recorded from Cecropia species is likely due to large number of seeds in each fruit. In addition, trees in this genus tend to be present in dense population groups, a process resulting from the anthropization of these areas.

The seed deposition pattern, with a predominance of pioneer species, can be interpreted as a positive contribution to the soil seed bank. The variety of seeds in this seed bank may result in different germination rates and seedling recruitment models. In addition, the presence of a wide variety of seeds is the central basis for ecological restoration (REIS et al., 2010; WIELAND et al., 2011).

Our statistical analysis of seed abundance at the different distances used for locating perches indicated that at distances up to 40 meters from the edge of the gallery forest, seed abundance was similar. However, the longest distance used $(80 \mathrm{~m})$ did affect the ability of birds to reach perches. However, it is not possible to say that these results would be the same if, for example, perches closer to the edge of the forest were removed, forcing the birds to seek more distant perches.

Dias et al. (2014) evaluated perches at different distances from the edge of a Restinga (tropical/subtropical moist broadleaf forest) and found that perches up to $35 \mathrm{~m}$ did not influence the relative abundance of zoochoric and anemochoric seeds. This result is similar to that found here. However, Dias et al. (2014) also reported that in Colombia and the Philippines, smaller distances $(20 \mathrm{~m})$ were enough to cause a decrease in the seed supply. Nathan et al. (2003) suggested that the ideal distances for seed transport are very variable and depend on factors such as the spatial structure of the environment and the avifaunal composition.

The lack of correlation found here between the rate of seed fall and monthly rainfall can be explained by the fact that the different groups of plants in the gallery forest areas show different flowering/fruiting seasons throughout the year. Flowering can occur at the beginning of the rainy season, at the end of the rains, or during the dry season. Athayde et al. (2009), in a study of the phenology of tree species in riverside forest in Santa Maria, state of Rio Grande do Sul, Brazil, found that the availability of fruit over the whole year was related to variations in temperature and photoperiod and not precipitation. This relationship results in the fruiting of trees at different times of the year and provides a relatively constant supply of food to different guilds, especially frugivores, but with peaks of greater and lesser availability. Bocchese et al. (2008) evaluated the relationship of rainfall and seed fall in the Cerrado area of the Campo Grande region and also found an absence of a relationship between seed fall rate and monthly precipitation.

The 77 bird species recorded in the present survey represents $8.99 \%$ of the 856 birds cataloged for the Cerrado (SILVA; SANTOS, 2005). However, it should be emphasized that this is a preliminary listing and that a greater number of species may be present. The high proportion of Passeriformes species recorded in the study area is a reflection of the fact that $414(49 \%)$ of bird species in the biome belong to this order (SILVA; SANTOS, 2005). The abundance of tyrant flycatcher species is a normal aspect of open and fragmented areas, since they are generalist birds and the group is one of the largest Brazilian bird families with 140 species (BISSOLI et al., 2014). 
The predominance of insectivorous and omnivorous species is in agreement with previous reports as these bird types were the most recorded in a study carried out in the Cerrado (SILVA; SANTOS, 2005). According to Fitzpatrick (1980), species within the Tyrannidae can be specialist or generalist feeders; the specialist species predominantly show the same behavior, although some variations in foraging activities are seen. Generalist species tend to show a range of behavior patterns.

Silva and Pedroni (2014) suggested that Passeriformes have an important role in the dispersal of seeds of plant species in disturbed areas. Omnivorous species occasionally consume fruits and seeds and are also considered potential dispersers. However, it is not possible to determine whether insectivorous species had an impact on the seed deposition process, since we did not specifically monitor which species used the perches, nor did we examine their foraging behavior or their guilds. Although typically frugivorous species were poorly represented in the survey, they may be responsible for most of the seeds taken to the perches.

Not all the frugivorous and omnivorous species identified here were considered to be potential dispersers: the proportion of $32.4 \%$ might be increased when it is considered that some insectivorous species feed on fruit. Some of the frugivorous and omnivorous species were not considered as potential dispersers because they did not use perches. For example, the rhea (Rhea americana), and undulated tinamou (Crypturellus undulatus), which are omnivores, and the spotted nothura (Nothura maculosa), a frugivore, are predominantly ground-dwelling and rarely use high structures in the landscape, such as perches.

The fact that a particular species of bird has an insectivorous diet does not necessarily mean that it only uses insects as food. Such species can also take advantage of other food sources, such as fruit, but on a smaller scale, and may therefore behave as generalist birds that contribute to the seed supply. Specific morphological adaptations are not necessary for the consumption of some fruits and/or seeds, allowing many species, such as tyrant flycatchers, to include these in their diet. As also noted by Rabello et al. (2010), the degree of fragmentation of a forest, and the size of the fragments, can be of importance as small forest areas can lead to the decline of specialist frugivorous species, to the benefit of generalist feeders due to the decrease in competition for fruit. In fragmented forests, the most specialized species tend to be replaced by generalists due to food restriction and/or habitat quality.

\section{CONCLUSION}

- Seed deposition on artificial perches was affected by distance from the edge of the gallery forest only at 80 meters; perches at shorter distances were preferred by seed dispersal birds.

- Although seeds of 27 plant species were collected, only seeds of Cecropia pachystachya and Myrsine coriacea were found in all months of the study.

- The abundance of the seeds collected was not directly related to periods of higher or lower rainfall in the region.

- Although there was variations in the abundance of seeds in different months, there was clearly a permanent availability of food resources for the birds of the area; consequently, dispersion and the incorporation of seeds in the soil were continuous throughout the year.

- The use of artificial perches influenced the seed deposition process and showed this method could be used in forest restoration.

\section{ACKNOWLEDGEMENTS}

The authors are grateful to the National Council of Scientific and Technological Development $(\mathrm{CNPq})$ for providing the Scientific Start-up Grant (PIBIC) and Presente Research Grant (PQ2) and Coordination of Improvement in Higher Education Personnel (CAPES) for scholarship. We would also like to thank the Foundation for the Development of Teaching, Science and Technology in Mato Grosso do Sul State (FUNDECT). Finally, we extend our thanks to the Anhanguera-Uniderp University for funding the Interdisciplinary Reseach Group (GIP project).

\section{REFERENCES}

ANJOS, L.; SCHUCHMANN, K. L.; BERNDT, R. A. Avifaunal composition, species richness, and status in the Tibagi River Basin, Parana State, southern Brazil. Ornitologia Neotropical, SON, v. 8, n. 2, p. 145-173, 1997.

FLORESTA, Curitiba, PR, v. 48, n. 3, p. 363-372, jul/set. 2018. 
ATHAYDE, E. A.; GIEHL, E. L. H.; BUDKE, J. C.; GESING, J. P. A.; EISINGER, S. M. Fenologia de espécies arbóreas em uma floresta ribeirinha em Santa Maria, sul do Brasil. Revista Brasileira de Biociências, Porto Alegre, v. 7, n. 1, p. 43-51, 2009.

ATHIÊ, S.; DIAS, M. M. Use of perches and seed dispersal by birds in an abandoned pasture in the Porto Ferreira state park, southeastern Brazil. Brazilian Journal of Biology, São Carlos, v. 76, n. 1, p. 80-92, 2016.

BISSOLI, L. B.; SOUZA, M. M.; ROPER, J. J. Espécies da família Tyrannidae partilham espaço de forrageio em um fragmento de Mata Atlântica, Brasil? Natureza on line, Santa Tereza, v. 12, n. 5, p. 235-239, 2014.

BOCCHESE, R. A.; OLIVEIRA, A. K. M.; FAVERO, S.; GARNÉS, S. J. A.; LAURA, V. A. Chuva de sementes e estabelecimento de plântulas a partir da utilização de árvores isoladas e poleiros artificiais por aves dispersoras de sementes, em área de Cerrado, Mato Grosso do Sul, Brasil. Revista Brasileira de Ornitologia, São Paulo, v. 16, n. 3, p. 207-213, 2008.

BRAGA, A. J. T.; BORGES, E. E. L.; MARTINS, S. V. Chuva de sementes em estádios sucessionais de Floresta Estacional Semidecidual em Viçosa-MG. Revista Árvore, Viçosa, v. 39, n. 3, p. 475-485, 2015.

CASTILLO, L. S.; STEVENSON, P. R. Relative importance of seed-bank and post-disturbance seed dispersal on early gap regeneration in a Colombian Amazon Forest. Biotropica, Wiley, v. 42, n. 4, p. 488-492, 2010.

CARLO, T. A.; YANG, S. Network models of frugivory and seed dispersal: challenges and opportunities. Acta Oecologica, Elsevier, v. 37, n. 6, p. 619-624, 2011.

CAVES, E. M.; JENNINGS, S. B.; HILLERISLAMBERS, J.; TEWKSBURY, J. J.; ROGERS, H. S. Natural experiment demonstrates that bird loss leads to cessation of dispersal of native seeds from intact to degraded forests. PLOS ONE, USA, v. 8, n. 5, p. e65618, 2013.

COTACIO, C. C.; MÚNERA, A. C.; RAMOS, J. M. Potencial del banco de semillas y la lluvia de semillas en la restauración natural de la Estación de Monitoreo de Biodiversidad del Centro de Investigaciones Amazónicas Macagual (Florencia-Caquetá, Colombia). Revista Momentos de Ciência, Caquetá, v. 6, n. 1, p. 21-31, 2009.

DIAS, C. R.; UMETSU, F.; BREIER, T. B. Contribuição dos poleiros artificiais na dispersão de sementes e sua aplicação na restauração florestal. Ciência Florestal, Santa Maria, v. 24, n. 2, p. 501-507, 2014.

FITZPATRICK, J. W. Foraging behavior of neotropical flycatchers. Condor, COS, v. 82, n. 1, p. 43-57, 1980.

GRAHAM, L. L. B.; PAGE, S. E. Artificial bird perches for the regeneration of degraded tropical peat swamp forest: a restoration tool with limited potential. Restoration Ecology, Wiley, v. 20, n. 5, p. 631-637, 2012.

NATHAN, R.; PERRY, G.; CRONIN, J. T.; STRAND, A. E.; CAIN, M. L. Methods for estimating long-distance dispersal. Oikos, Wiley, v. 103, n. 2, p. 261-273, 2003.

RABELLO, A.; RAMOS, F. N.; HASUI, É. Efeito do tamanho do fragmento na dispersão de sementes de Copaíba (Copaifera langsdorffii Delf.). Biota Neotropica, São Paulo, v. 10, n. 1, p. 47-54, 2010.

REIS, A.; BECHARA, F. C.; TRES, D. R. Nucleation in tropical ecological restoration. Scientia Agricola, Piracicaba, v. 67, n. 2, p. 244-250, 2010.

SICK, H. Ornitologia Brasileira. São Paulo: Nova Fronteira, 1997. 862p.

SILVA, J. M. C.; SANTOS, M. P. D. A importância relativa dos processos biogeográficos na formação da avifauna do Cerrado e de outros biomas brasileiros. In: SCARIOT, A.; SOUSA-SILVA, J. C.; FELFILI, J. M. (Eds). Cerrado: ecologia, biodiversidade e conservação. Brasília: Ministério do Meio Ambiente, 2005. p. 220- 233.

SILVA, G. B. M.; PEDRONI, F. Frugivoria por aves em área de cerrado no município de Uberlândia, Minas Gerais. Revista Árvore, Viçosa, v. 38, n. 3, p. 433-442, 2014.

WIELAND, L. M.; MESQUITA, R. C. G.; BOBROWIEC, P. E. D.; BENTOS, T. V.; WILLIAMSON, G. B. Seed rain and advance regeneration in secondary succession in the Brazilian Amazon. Tropical Conservation Science, SAGE, v. 4, n. 33, p. 300-316, 2011.

ZIMMERMANN, A. P. L.; FLEIG, F. D.; MARANGON, G. P. Determinação da distância de dispersão efetiva de Cabralea canjerana. Floresta e Ambiente, Seropédica, v. 22, n. 2, p. 204-210, 2015. 